\title{
ENVIRONMENTAL ROLE OF URBAN LANDSCAPE INDICATORS IN OLDER DISTRICTS OF CITIES
}

\author{
Ayin Hosseini \\ Department of Urban Design, Tabriz Branch, Islamic Azad University, Tabriz, Iran; \\ *Corresponding author: Ayin Hosseini, e-mail: iilin.hosini@gmail.com; \\ Received February, 2018; Accepted March, 2018; Published April, 2018; \\ doi: https://doi.org/10.31407/ijees8310 \\ UOI license: $\underline{\text { http://u-o-i.org/1.01/ijees/03750153 }}$
}

\begin{abstract}
Despite the challenges of urban ecology and sustainability in older districts of cities in Iran, the environmental impacts of factors related to urban landscape on well-being of citizens, from a scientific point of view are yet to be studied. An environmental well-being indicator as a tool can be used for the assessment and monitoring of the impact of urban landscape on sustainable urban development and transformation of societies in the direction of urban sustainability, especially in older districts of cities. This study, therefore, was intended to develop a valid framework for environmental well-being indicators related to urban landscape for urban sustainability in older districts of cities, using Delphi method. The participants were selected among urban planning and design scholars and urban managers in EastAzarbaijan Province, Iran.
\end{abstract}

Keywords: ecology, landscape, urbanization 